\title{
Methylglyoxal modulates endothelial nitric oxide synthase-associated functions in EA.hy926 endothelial cells
}

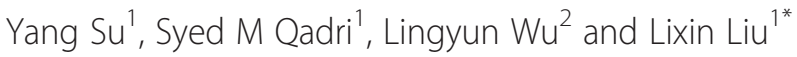

\begin{abstract}
Background: Increased levels of the sugar metabolite methylglyoxal (MG) in vivo were shown to participate in the pathophysiology of vascular complications in diabetes. Alterations of endothelial nitric oxide synthase (eNOS) activity by hypophosphorylation of the enzyme and enhanced monomerization are found in the diabetic milieu, and the regulation of this still remains undefined. Using various pharmacological approaches, we elucidate putative mechanisms by which MG modulates eNOS-associated functions of MG-stimulated superoxide $\left(\mathrm{O}_{2}^{--}\right)$production, phosphorylation status and eNOS uncoupling in EA.hy926 human endothelial cells.

Methods: In cultured EA.hy926 endothelial cells, the effects of MG treatment, tetrahydrobiopterin (BH4; $100 \mu \mathrm{M})$ and sepiapterin $(20 \mu \mathrm{M})$ supplementation, NOS inhibition by $N^{G}$-nitro-L-arginine methyl ester (L-NAME; $50 \mu M$ ), and inhibition of peroxynitrite $\left(\mathrm{ONOO}^{-}\right.$) formation (300 $\mu \mathrm{M}$ Tempol plus $50 \mu \mathrm{M}$ L-NAME) on eNOS dimer/monomer ratios, Ser-1177 eNOS phosphorylation and 3-nitrotyrosine (3NT) abundance were quantified using immunoblotting. $\mathrm{O}_{2}^{--}$-dependent fluorescence was determined using a commercially available kit and tissue biopterin levels were measured by fluorometric HPLC analysis.

Results: In EA.hy926 cells, MG treatment significantly enhanced $\mathrm{O}_{2}^{-}$generation and 3NT expression and reduced Ser-1177 eNOS phosphorylation, eNOS dimer/monomer ratio and cellular biopterin levels indicative of eNOS uncoupling. These effects were significantly mitigated by administration of $\mathrm{BH}_{4}$, sepiapterin and suppression of ONOO ${ }^{-}$formation. L-NAME treatment significantly blunted eNOS-derived $\mathrm{O}_{2}^{--}$generation but did not modify eNOS phosphorylation or monomerization.

Conclusion: MG triggers eNOS uncoupling and hypophosphorylation in EA.hy926 endothelial cells associated with $\mathrm{O}_{2}^{-}$ generation and biopterin depletion. The observed effects of the glycolysis metabolite MG presumably account, at least in part, for endothelial dysfunction in diabetes.
\end{abstract}

Keywords: Methylglyoxal, eNOS uncoupling, Superoxide, Tyrosine nitration, Biopterins, eNOS phosphorylation

\section{Introduction}

Chronic hyperglycemia fosters endothelial dysfunction that accounts for the pathophysiology of microvascular sequelae in diabetes $[1,2]$. The elevated glycolysis metabolite methylglyoxal (MG) has been implicated in vascular complications such as hypertension [3], impaired microcirculation [4] and thrombosis [5] in diabetes. The increased MG affects multi-organ homeostasis by modulating immune cell functions [6], cytokine induction [7], cytosolic $\mathrm{Ca}^{2+}[8]$, cellular energy and redox balance [9] and adhesion molecules expression [10] and induces both necrotic [11] and apoptotic cell death [4].

\footnotetext{
* Correspondence: lixin.liu@usask.ca

${ }^{1}$ Department of Pharmacology, College of Medicine, University of Saskatchewan, 107 Wiggins Road, Saskatoon, SK, Canada

Full list of author information is available at the end of the article
}

Endothelial nitric oxide synthase (eNOS) is the predominant and constitutively expressed NOS in vascular endothelial cells and catalyzes the reaction for generation of nitric oxide (NO) from L-arginine in the presence of the cofactors tetrahydrobiopterin (BH4) and NADPH [12]. Regulation of eNOS activity is coupled to cytosolic $\mathrm{Ca}^{2+}[13]$ whereas the expression is regulated by a wide range of transcriptional and posttranscriptional mechanisms [14]. Alterations of NO balance contribute to the pathophysiology of diabetic complications [15]. Deficiency of either L-arginine or $\mathrm{BH} 4$ results in reduced $\mathrm{NO}$ but enhanced superoxide $\left(\mathrm{O}_{2}^{--}\right)$production, a functional change of eNOS that is defined as eNOS uncoupling [12]. eNOS uncoupling is associated with increased eNOS monomerization, tyrosine nitration and formation of dihydrobiopterin (BH2) and

\section{() Biomed Central}

(c) 2013 Su et al.; licensee BioMed Central Ltd. This is an open access article distributed under the terms of the Creative Commons Attribution License (http://creativecommons.org/licenses/by/2.0), which permits unrestricted use, distribution, and reproduction in any medium, provided the original work is properly cited. 
decreased cellular BH4 $[16,17]$. Sepiapterin is a stable precursor of $\mathrm{BH} 4$ and serves as a valuable pharmacological agent for the study of eNOS uncoupling due to its high cell permeability as compared to $\mathrm{BH} 4[18,19]$. $\mathrm{O}_{2}^{--}$avidly reacts with $\mathrm{NO}$ to form peroxynitrite $\left(\mathrm{ONOO}^{-}\right)$which triggers the oxidation of $\mathrm{BH} 4$, impairs eNOS activity and induces eNOS uncoupling $[12,16,20]$.

Uncoupling of eNOS is the underlying mechanism of endothelial dysfunction associated with cardiovascular conditions such as hypertension, stroke, and heart failure $[21,22]$. Recently, eNOS uncoupling was shown to participate in endothelial dysfunction in diabetic mice [23] and to mediate peripheral neuropathy in diabetic rats [24]. In Zucker diabetic fatty rats, endothelial dysfunction and decreased NO availability were attributed to dissociation of eNOS from HSP90, an effect elicited by increased calpain activity [25]. As a myriad of molecules are dysregulated in diabetes, the specific effects of MG on eNOS uncoupling, however, remain elusive.

Ramifications of elevated MG levels in hyperglycemia include impaired NO production and redox imbalance [26]. Various studies promulgate a possible link between endothelial dysfunction and functional alterations of eNOS after MG treatment. To date, however, discrepant data prevail on MG sensitivity of eNOS functions in different model systems. On the one hand, MG was shown to stimulate transcription of eNOS [27]; while on the other, abundance of eNOS protein was reduced following MG treatment $[28,29]$. In contrast, MG was shown to suppress eNOS phosphorylation on serine-1179 without affecting eNOS protein expression [30]. Increased MG levels in preeclamptic vasculature were shown to be coupled with enhanced arginase, LOX-1 and tyrosine nitration [31]. The association between MG-triggered eNOS phosphorylation, eNOS uncoupling, and oxidative stress in vascular endothelial dysfunction, however, remains ill-defined.

The present study explores the mechanisms of MGinduced endothelial dysfunction by examining putative eNOS-associated functions. We elucidate the effects of exogenous $\mathrm{BH} 4$ and sepiapterin administration, NOS inhibition and suppression of peroxynitrite $\left(\mathrm{ONOO}^{-}\right)$formation on $\mathrm{O}_{2}^{--}$generation, eNOS monomerization, cellular biopterin levels, tyrosine nitration, and phosphorylation of eNOS in EA.hy926 endothelial cells in vitro.

\section{Materials and methods}

\section{Cell culture and pharmacological treatments}

EA.hy926 cells, the hybrid human umbilical vein endothelial cell line cells [32], were obtained from American Type Culture Collection (Rockville, MD, USA) and cultured in Dulbecco's modified Eagle's medium (Cellgro, VA, USA) with $10 \%$ fetal bovine serum (Hyclone, UT, USA), $100 \mathrm{U} / \mathrm{mL}$ penicillin and $100 \mu \mathrm{g} / \mathrm{mL}$ streptomycin (Amresco, $\mathrm{OH}, \mathrm{USA}$ ) with $5 \% \mathrm{CO}_{2}$ and maximal humidity at $37^{\circ} \mathrm{C}$. Cells between passage 3 and 6 were used for the experiments. As indicated in the figure legends, various pharmacological approaches were used to elucidate eNOS-associated functions. To maintain eNOS dimerization, the NOS cofactor 5,6,7, 8-tetrahydrobiopterin (BH4, $100 \mu \mathrm{M}$; Sigma-Aldrich, Oakville, ON, Canada) or the negative control, a pteridine analogue, 5,6,7,8-tetrahydroneopterin (NH4, $100 \mu \mathrm{M}$; Schircks Laboratories, Jona, Switzerland) were freshlyprepared and administered. NH4 has similar antioxidant effects as BH4 but, unlike BH4, is ineffective in restoring uncoupled eNOS [33]. Sepiapterin ( $20 \mu \mathrm{M}$; Cayman, Ann Arbor, MI, USA), a substrate for $\mathrm{BH} 4$ synthesis via the pterin salvage pathway, was used to increase cellular BH4 levels [34]. The NOS inhibitor $\mathrm{N}^{\mathrm{G}}$-nitro-L-arginine methyl ester (L-NAME, $50 \mu \mathrm{M}$; Sigma-Aldrich), was administered to inhibit uncoupled eNOS-derived $\mathrm{O}_{2}^{*-}$ [35]. For suppression of $\mathrm{ONOO}^{-}$generation, EA.hy926 cells were treated with a combination of the ROS scavenger 1-oxyl-2,2,6, 6-tetramethyl-4-hydroxypiperidine (Tempol, $300 \mu M$; Santa Cruz, Dallas, TX, USA) and NOS inhibitor L-NAME $(50 \mu \mathrm{M})$ for $24 \mathrm{~h}$ prior to the addition of MG $[36,37]$. $\mathrm{O}_{2}^{*-}$ reacts with $\mathrm{NO}$ at equimolar ratio to generate $\mathrm{ONOO}^{-}$[36], and from our unpublished observations, pretreatment with a combination of L-NAME and Tempol more potently inhibits $\mathrm{ONOO}^{-}$formation than pretreatment with either pharmacological agent alone.

\section{Determination of $\mathrm{O}_{2}^{--}$production}

$\mathrm{O}_{2}^{--}$levels were determined using a commercial superoxide detection kit (Enzo, Brockville, ON, Canada) according to the manufacturer's instructions as described previously [38,39]. The superoxide detection reagent when oxidized produces an orange fluorescent compound which is retained in the cell. Cells were seeded in a 96-well plate and stained with the membranepermeable and nonfluorescent $\mathrm{O}_{2}^{--}$detection probe $(5 \mu \mathrm{M}$, $30 \mathrm{~min}, 37^{\circ} \mathrm{C}$ in the dark). Excessive probe was removed by washing with PBS. The fluorescence in cells was detected using excitation and emission wavelengths of 544 $\mathrm{nm}$ and $590 \mathrm{~nm}$ respectively. The data are expressed as arbitrary units.

\section{Analysis of biopterin levels by HPLC}

Measurement of $\mathrm{BH} 4$ and total biopterins was performed by fluorometric HPLC analysis as described previously with slight modifications [35]. After indicated treatments, EA.hy926 cells were lysed in a lysis buffer (pH 7.4; containing $50 \mathrm{mM}$ Tris-HCl, $1 \mathrm{mM}$ DTT and 1 $\mathrm{mM}$ EDTA) with $0.1 \mu \mathrm{M}$ neopterin (Sigma-Aldrich) as an internal recovery standard. The samples were deproteinated with 10\% 1:1 mixture of $1.5 \mathrm{M} \mathrm{HClO}_{4}$ and $2 \mathrm{M} \mathrm{H}_{3} \mathrm{PO}_{4}$ and centrifuged $(12,000 \times \mathrm{g}$ for $10 \mathrm{~min})$. The supernatant was split into portions and subjected to 
acid- and alkali-oxidation respectively. For determination of total biopterins (BH4, $\mathrm{BH} 2$ and non-reduced biopterins) by acid-oxidation, $10 \mu \mathrm{l}$ iodine solution (1\% iodine in $2 \% \mathrm{KI}$ solution) was added into each $90 \mu \mathrm{l}$ supernatant and for quantification of $\mathrm{BH} 2$ and nonreduced biopterins by alkali-oxidation, $10 \mu \mathrm{l}$ of $1 \mathrm{M}$ $\mathrm{NaOH}$ and $10 \mu \mathrm{l}$ of iodine solution were added to $80 \mu \mathrm{l}$ supernatant. Following incubation $(1 \mathrm{~h}$, room temperature in the dark), the alkali-oxidation samples were acidified with $1 \mathrm{M} \mathrm{H}_{3} \mathrm{PO}_{4}$, the iodine in both acid- and alkali-oxidation samples was reduced using $5 \%$ ascorbic acid (Sigma) and the samples were centrifuged (12,000 $\times$ $\mathrm{g}$ for $10 \mathrm{~min}$ ). The supernatant was collected for HPLC analysis using a Hitachi D-7000 HPLC system (Hitachi, Mississauga, ON, Canada) via Symmetry C18 reversephase column with a methanol-water $(1.5: 98.5, \mathrm{v} / \mathrm{v})$ mobile phase running at $0.5 \mathrm{~mL} / \mathrm{min}$. Fluorescence was detected at excitation and emission wavelengths of 348 $\mathrm{nm}$ and $444 \mathrm{~nm}$ respectively. The level of BH4 was calculated by subtracting $\mathrm{BH} 2$ and non-reduced biopterins from total biopterins and expressed as pmol per mg protein. The biopterin levels in NH4-treated cells were calculated without adding $0.1 \mu \mathrm{M}$ neopterin.

\section{Western blotting}

Non-reducing SDS-PAGE was performed to detect eNOS dimers and monomers [35]. Briefly, cultured EA. hy926 cells were harvested and lysed on ice for $30 \mathrm{~min}$ by using RIPA buffer $(50 \mathrm{mM}$ Tris- $\mathrm{HCl}, 150 \mathrm{mM} \mathrm{NaCl}$, $1 \%$ NP-40, $0.5 \%$ sodium deoxycholate, $0.1 \%$ SDS and protease inhibitors cocktail, $\mathrm{pH}$ 8.0). The lysate was centrifuged at $10,000 \times \mathrm{g}$ for $10 \mathrm{~min}$, and the supernatant was collected, incubated with $4 \times$ Laemmli buffer without $\beta$-mercaptoethanol (200 mM Tris- $\mathrm{HCl}, 50 \%$ glycerol, 2\% SDS, $0.04 \%$ bromophenol blue, $\mathrm{pH}$ 6.8) at $37^{\circ} \mathrm{C}$ for $5 \mathrm{~min}$. Aliquots of cell lysates (50 $\mu \mathrm{g}$ of protein each) were separated on 7\% SDS-PAGE. Gels and buffers were equilibrated at $4^{\circ} \mathrm{C}$ before electrophoresis, and the buffer tank was placed in an ice bath during electrophoresis to maintain the low temperature. Subsequent to non-reducing SDS-PAGE, the gels were electrotransferred to a nitrocellulose membrane (Bio-Rad, CA, USA), and the blots were probed by primary antibody against eNOS (1:1000; BD Pharmingen, USA) and horseradish peroxidase-conjugated secondary antibody (Santa Cruz) as routine Western blot. In separate gels, total eNOS (1:1000), $\beta$-actin (1:1000; Santa Cruz, CA, USA), phospho-eNOS (Ser-1177, 1:1000; BD Pharmingen, CA, USA) and 3-nitrotyrosine (3NT, 1:1000; Enzo) from cell lysates of the same experiments were detected by routine Western blot under reduced condition. The bands were visualized with enhanced chemiluminescence reagents (GE Healthcare Life Sciences, NJ, USA) and exposed to X-ray film (Kodak scientific imaging film, ON,
Canada). Densitometric quantification of the detected bands was performed using Quantity One ${ }^{\circ}$ Software (Bio-rad). The ratio of eNOS dimer to monomer was normalized to one in the absence of MG.

\section{Statistical analysis}

Data are expressed as arithmetic means \pm SEM from at least three independent experiments. Statistical analysis was made using one way analysis of variance (ANOVA) with Tukey's post-hoc comparison test. $\mathrm{n}$ denotes the number of different batches of cells tested in each treatment group. Values of $\mathrm{p}<0.05$ were considered statistically significant.

\section{Results}

To elucidate the redox imbalance triggered by MG treatment on vascular endothelial cells in vitro, we analyzed MG-triggered $\mathrm{O}_{2}^{--}$generation using a fluorescence-based assay. Treatment of EA.hy926 endothelial cells with MG $(50-200 \mu \mathrm{M})$ for $2,4,6$ and $8 \mathrm{~h}$ respectively, significantly increased $\mathrm{O}_{2}^{+-}$production in a concentration- and timedependent manner (Figure 1A). In another series of experiments, we analyzed the effect of biopterin supplementation (BH4, $100 \mu \mathrm{M}$; sepiapterin, $20 \mu \mathrm{M}$ ), pharmacological inhibition of NOS using L-NAME $(50 \mu \mathrm{M})$ or suppression of $\mathrm{ONOO}^{-}$formation using combined 24-h pretreatment with Tempol $(300 \mu \mathrm{M})$ and L-NAME $(50 \mu \mathrm{M})$ on MGinduced $\mathrm{O}_{2}^{--}$production. As shown in Figure 1B, inhibition of NOS, suppression of $\mathrm{ONOO}^{-}$formation, or supplementation of either $\mathrm{BH} 4$ or sepiapterin significantly attenuated MG-induced $\mathrm{O}_{2}^{--}$production. Treatment of EA.hy926 cells with the BH4 control NH4 $(100 \mu \mathrm{M})$, however, did not significantly alter MG-induced $\mathrm{O}_{2}^{--}$production (Figure 1B). These results suggest eNOS-derived $\mathrm{O}_{2}^{*-}$ production in MG-treated EA.hy296 endothelial cells.

Next, we explored the effect of MG on eNOS monomerization in EA.hy926 endothelial cells. Treatment of EA. hy926 cells with MG $(50-200 \mu \mathrm{M})$ for $0.5,2,4$, and $8 \mathrm{~h}$ respectively, significantly decreased eNOS dimer/monomer ratio in a concentration- and time-dependent manner (Figure 2A and 2B). These results, together with the effect of L-NAME inhibition on MG-induced $\mathrm{O}_{2}^{*-}$ production (Figure 1B), suggest that MG treatment induces eNOS uncoupling in EA.hy926 cells. We further tested the effect of biopterin supplementation, L-NAME addition and suppression of $\mathrm{ONOO}^{-}$formation on MG-elicited eNOS monomerization. As shown in Figure $2 \mathrm{C}$ and $2 \mathrm{D}$, treatment of EA.hy926 cells with MG $(100 \mu \mathrm{M})$ for $8 \mathrm{~h}$ significantly reduced eNOS dimer/monomer ratio, an effect that was significantly blunted by the administration of $\mathrm{BH} 4$ $(100 \mu \mathrm{M}, 4 \mathrm{~h})$, sepiapterin $(20 \mu \mathrm{M}, 4 \mathrm{~h})$ or by $\mathrm{ONOO}^{-}$ suppression ( $300 \mu \mathrm{M}$ Tempol and $50 \mu \mathrm{M}$ L-NAME, $24 \mathrm{~h}$ ). Treatment with L-NAME $(50 \mu \mathrm{M}, 4 \mathrm{~h})$ alone or the BH4 control NH4 $(100 \mu \mathrm{M}, 4 \mathrm{~h})$ did not modify eNOS dimer/ monomer ratio (Figure $2 \mathrm{C}$ and $2 \mathrm{D}$ ). 


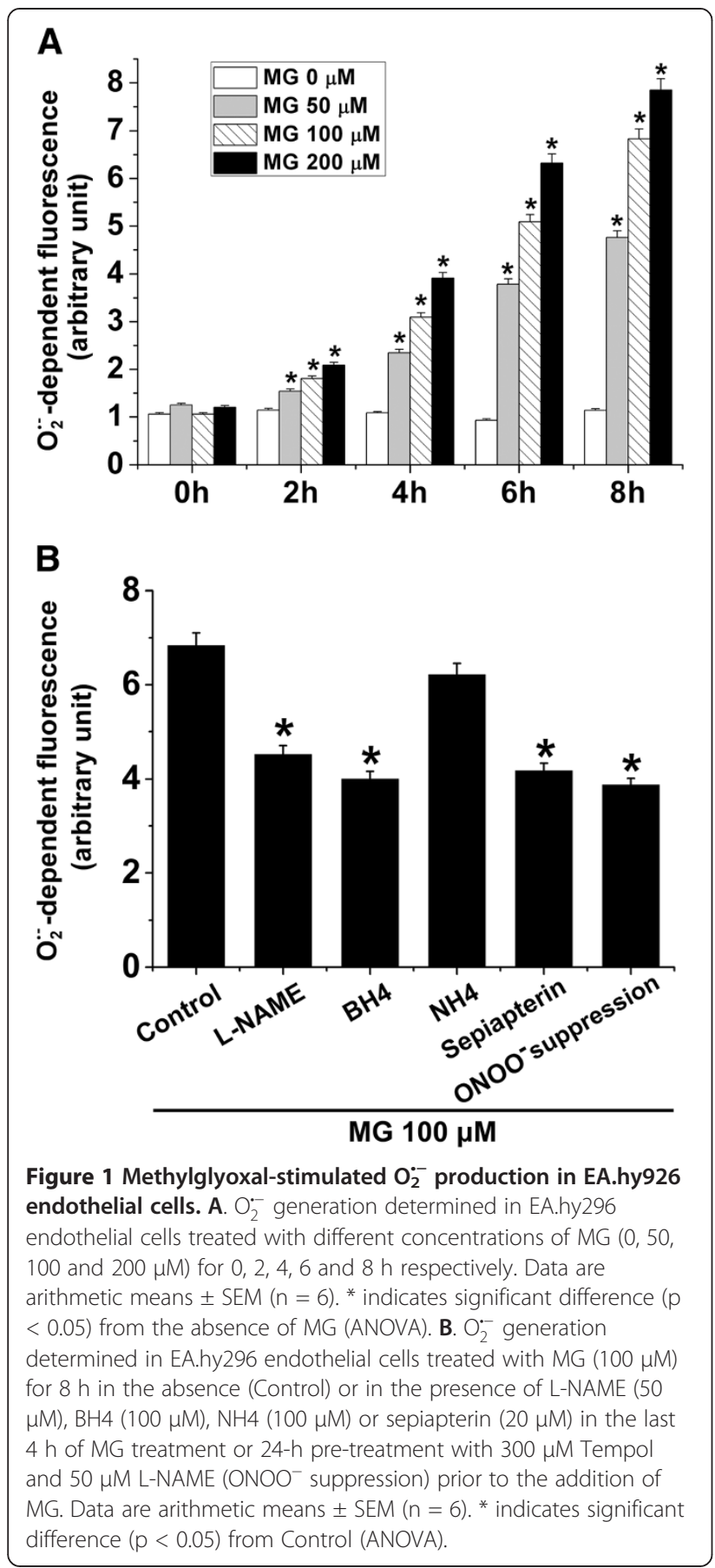

To further elucidate MG-induced eNOS uncoupling, we determined the cellular BH4 levels in EA.hy926 cells following MG treatment. As depicted in Figure 3A, treatment of EA.hy926 cells with MG $(50-200 \mu \mathrm{M})$ for $8 \mathrm{~h}$ significantly decreased total cellular biopterin and BH4 levels in a concentration-dependent manner. More importantly, treatment of EA.hy926 cells resulted in a reduction of $\mathrm{BH} 4 /$ total biopterin ratio, an effect reaching statistical significance at $100 \mu \mathrm{M}$ MG concentration



B

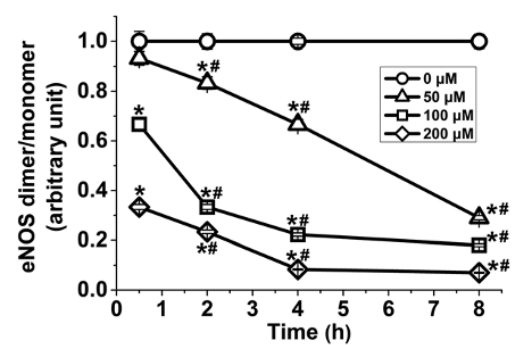

C
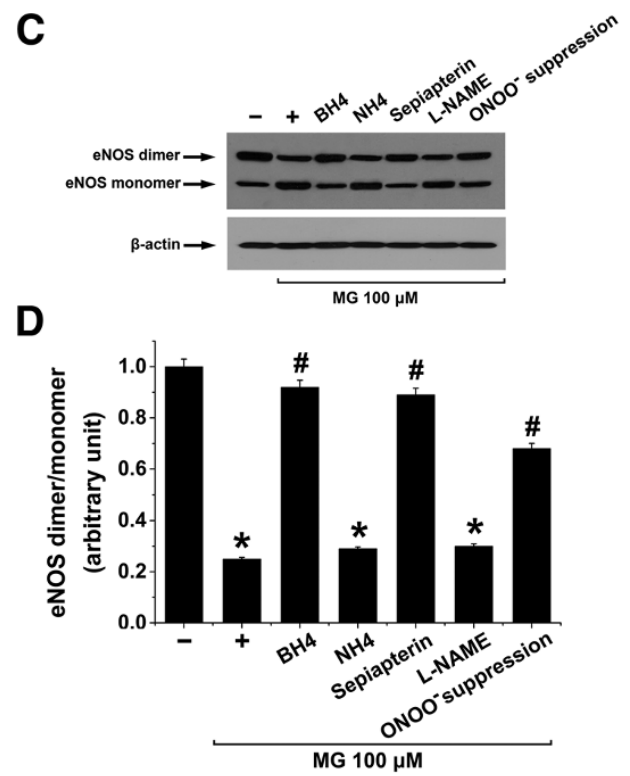

Figure 2 Methylglyoxal-induced eNOS monomerization in EA. hy926 endothelial cells. A and B. Original Western blots (A) and the respective densitometric analysis (B) of the relative abundance of eNOS dimers over eNOS monomers (relative to $\beta$-actin) in EA.hy296 endothelial cells treated with different concentrations of $M G(0 \mu M$, circles; $50 \mu \mathrm{M}$, triangles; $100 \mu \mathrm{M}$, squares; and $200 \mu \mathrm{M}$, diamonds) for $0.5,2,4$, and $8 \mathrm{~h}$ respectively. Data are arithmetic means \pm SEM $(\mathbf{A}$, representative of five experiments; $\mathbf{B}, n=5)$. * indicates significant difference $(p<0.05)$ from the absence of MG (ANOVA). \# indicates significant difference $(p<0.05)$ from time 0.5 h (ANOVA). $C$ and $\mathbf{D}$. Original Western blots (C) and the respective densitometric analysis (D) of the relative abundance of eNOS dimers over eNOS monomers (relative to $\beta$-actin) in EA.hy296 endothelial cells incubated in the absence $(-)$ or in the presence of MG $(100 \mu \mathrm{M})$ for $8 \mathrm{~h}$ alone $(+)$ or with $100 \mu \mathrm{M} \mathrm{BH4}, 100 \mu \mathrm{M} \mathrm{NH} 4,20 \mu \mathrm{M}$ sepiapterin or $50 \mu \mathrm{M}$ L-NAME in the last $4 \mathrm{~h}$ of MG treatment or with 24-h pre-treatment with $300 \mu \mathrm{M}$ Tempol and $50 \mu \mathrm{M}$ L-NAME (ONOO- suppression). Data are arithmetic means \pm SEM (C, representative of four experiments; $\mathbf{D}, n=4)$. * indicates significant difference $(p<0.05)$ from the absence of MG (ANOVA). \# indicates significant difference $(p<0.05)$ from MG treatment alone (ANOVA). 
A
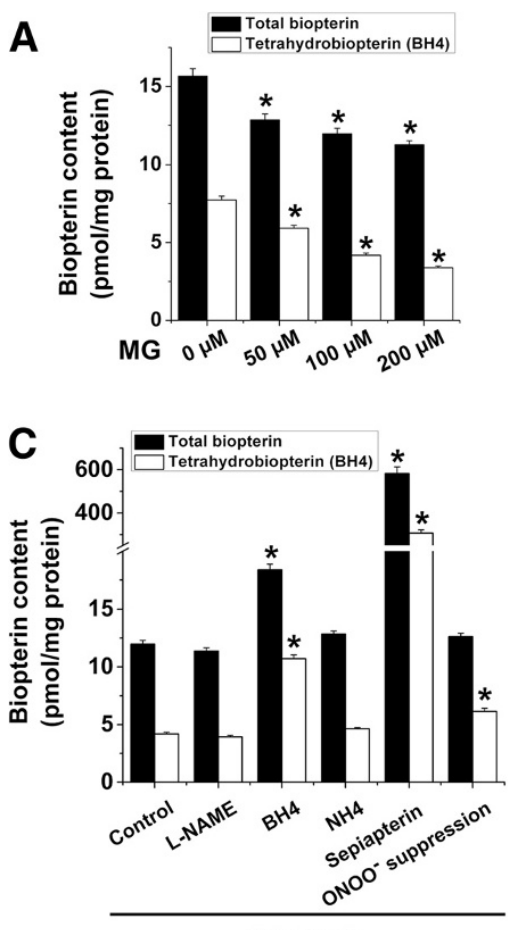

B
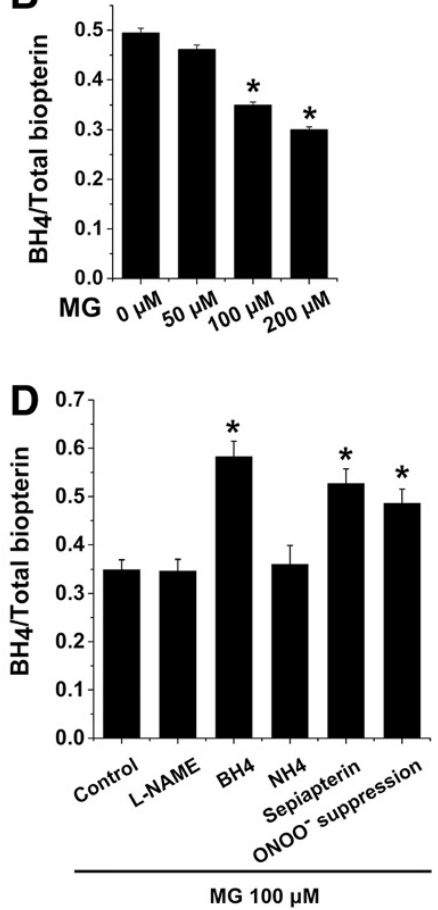

Figure 3 Effect of methylglyoxal on cellular biopterin levels in EA.hy926 endothelial cells. A and B. Total cellular biopterin (pmol/mg protein; black bars; A) and BH4 (pmol/mg protein; white bars; $\mathbf{A}$ ) and the respective BH4/total biopterin ratio (B) determined in EA.hy296 endothelial cells treated with different concentrations of $M G(0,50,100$ and $200 \mu M)$ for $8 \mathrm{~h}$. Data are arithmetic means \pm SEM $(n=5)$. * indicates significant difference $(p<0.05$ ) from the absence of MG (ANOVA). $\mathbf{C}$ and $\mathbf{D}$. Total cellular biopterin (pmol/mg protein; black bars; $\mathbf{C}$ ) and BH4 (pmol/mg protein; white bars; $\mathbf{C}$ ) and the respective BH4/total biopterin ratio (D) determined in EA.hy296 endothelial cells treated with MG $(100 \mu \mathrm{M})$ for $8 \mathrm{~h}$ in the absence (Control) or in the presence of L-NAME $(50 \mu \mathrm{M}), \mathrm{BH} 4(100 \mu \mathrm{M}), \mathrm{NH} 4(100 \mu \mathrm{M})$ or sepiapterin $(20 \mu \mathrm{M})$ in the last $4 \mathrm{~h}$ of MG treatment or with 24-h pre-treatment with $300 \mu \mathrm{M}$ Tempol and $50 \mu \mathrm{M}$ L-NAME (ONOO- suppression). Data are arithmetic means \pm SEM $(n=5)$. * indicates significant difference $(p<0.05)$ from Control (ANOVA).

(Figure 3B). We then explored the effect of biopterin supplementation, L-NAME addition and suppression of $\mathrm{ONOO}^{-}$formation on MG-induced reduction in cellular BH4 levels. As illustrated in Figure 3C, 4-h supplementation of BH4 $(100 \mu \mathrm{M})$ or sepiapterin $(20 \mu \mathrm{M})$ in MGtreated EA.hy926 cells significantly increased total cellular biopterin and BH4 levels suggesting that exogenous biopterin repletion dissipated MG-induced reduction in cellular BH4 contents associated with eNOS uncoupling. Suppression of $\mathrm{ONOO}^{-}$, however, did not significantly modify total cellular biopterin levels but significantly increased cellular BH4 levels in MG-treated cells (Figure 3C). Neither the BH4 control NH4 $(100 \mu \mathrm{M})$ nor L-NAME (50 $\mu \mathrm{M})$ alone significantly altered cellular $\mathrm{BH} 4$ and total biopterin levels (Figure 3C). Similarly, MG-induced reduction of cellular BH4/total biopterin ratio was significantly attenuated by supplementation with $\mathrm{BH} 4$ or sepiapterin or by $\mathrm{ONOO}^{-}$suppression but not by the $\mathrm{BH} 4$ control NH4 or by L-NAME alone (Figure 3D).

Uncoupling of eNOS is associated with enhanced cellular nitration of tyrosine [17]. In a further series of experiments we examined the abundance of $3 \mathrm{NT}$ in EA. hy926 cells treated with MG and the effect of biopterins, LNAME or $\mathrm{ONOO}^{-}$suppression after MG. As shown in Figure 4, treatment of EA.hy926 cells with $100 \mu \mathrm{M}$ of MG for $8 \mathrm{~h}$ significantly increased the expression of $3 \mathrm{NT}$, an effect that was significantly blunted by BH $4(100 \mu \mathrm{M}, 4 \mathrm{~h})$, sepiapterin $(20 \mu \mathrm{M}, 4 \mathrm{~h})$ or $\mathrm{ONOO}^{-}$suppression $(300 \mu \mathrm{M}$ Tempol and $50 \mu \mathrm{M}$ L-NAME, $24 \mathrm{~h}$ ) but not by the BH4 control NH4 $(100 \mu \mathrm{M}, 4 \mathrm{~h})$ or L-NAME $(50 \mu \mathrm{M}, 4 \mathrm{~h})$ suggesting that biopterin-sensitive eNOS uncoupling was triggered by MG (Figure 4A and 4B). The effect of $\mathrm{ONOO}^{-}$ suppression on the reduction of 3NT expression by the combination of Tempol $(300 \mu \mathrm{M})$ and L-NAME $(50 \mu \mathrm{M})$ was higher than the administration of Tempol $(300 \mu \mathrm{M})$ alone (data not shown).

To further unravel the modulation of eNOS functions by MG, we investigated the effect of biopterin supplementation, $\mathrm{ONOO}^{-}$suppression and NOS inhibition on eNOS phosphorylation (Ser-1177) associated with eNOS uncoupling. To this end, treatment of EA.hy926 cells with $100 \mu \mathrm{M}$ of MG for $8 \mathrm{~h}$ did not modify total eNOS but significantly decreased phosphorylation of eNOS (Ser-1177), an effect that was significantly blunted by 


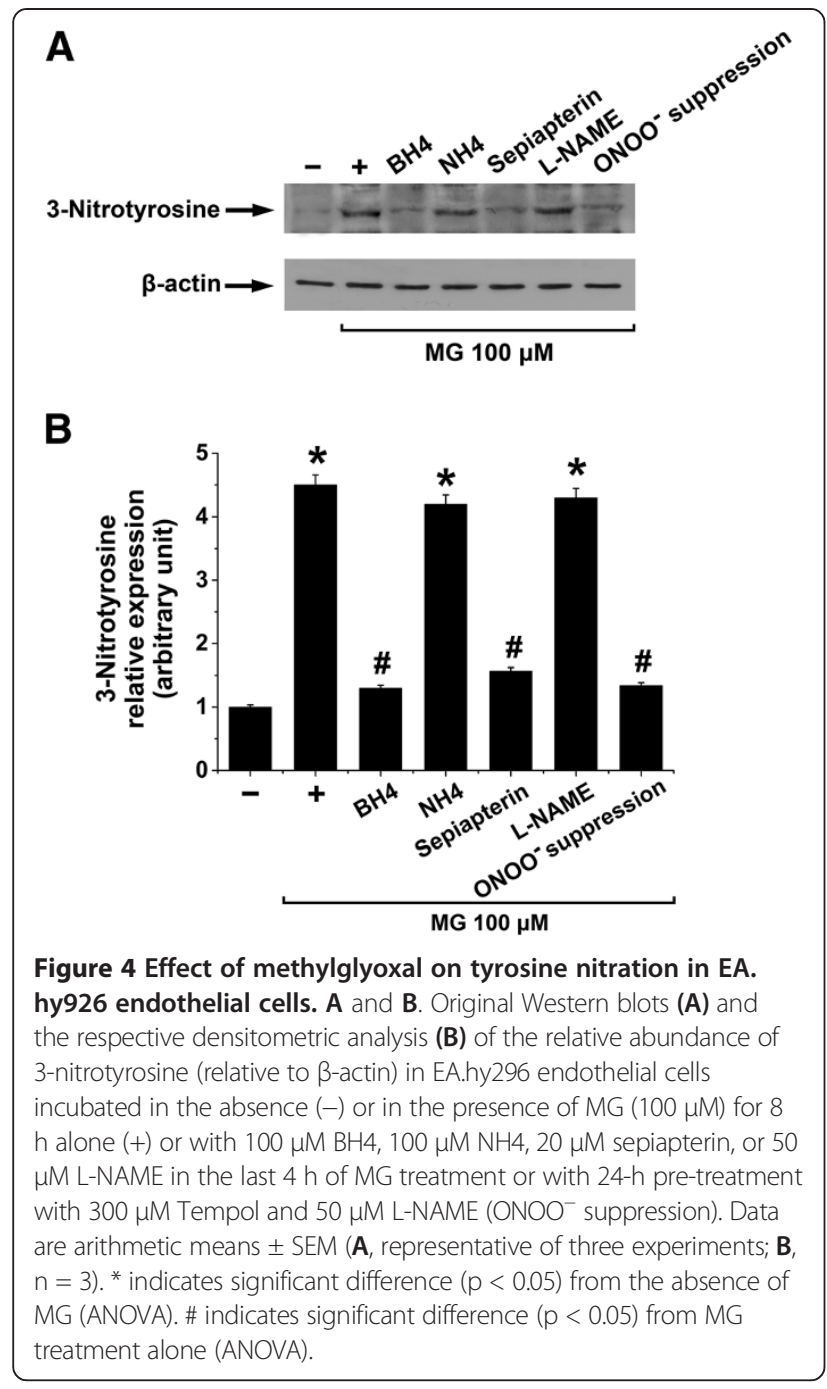

BH4 $(100 \mu \mathrm{M})$, sepiapterin $(20 \mu \mathrm{M})$ or $\mathrm{ONOO}^{-}$suppression but not by the BH4 control NH4 $(100 \mu \mathrm{M})$ or LNAME $(50 \mu \mathrm{M})$ suggesting that both eNOS phosphorylation (Ser-1177) and eNOS uncoupling are closely linked to MG-triggered endothelial dysfunction (Figure 5A and 5B).

\section{Discussion}

In this study we provide conclusive biological evidence that treatment of EA.hy926 endothelial cells with MG triggers eNOS hypophosphorylation and eNOS uncoupling in vitro. We show that MG treatment enhances $\mathrm{O}_{2}^{--}$ generation and 3NT expression and decreases Ser-1177 phosphorylated eNOS, eNOS dimer/monomer ratio and cellular levels of $\mathrm{BH} 4$ and $\mathrm{BH} 4 /$ total biopterin ratio in endothelial cells. Moreover, we demonstrate that pharmacological suppression of eNOS uncoupling by L-NAME, exogenous $\mathrm{BH} 4$ or sepiapterin administration, and $\mathrm{ONOO}^{-}$suppression counteracted MG-induced eNOS uncoupling, 3NT upregulation and eNOS hypophosphorylation.
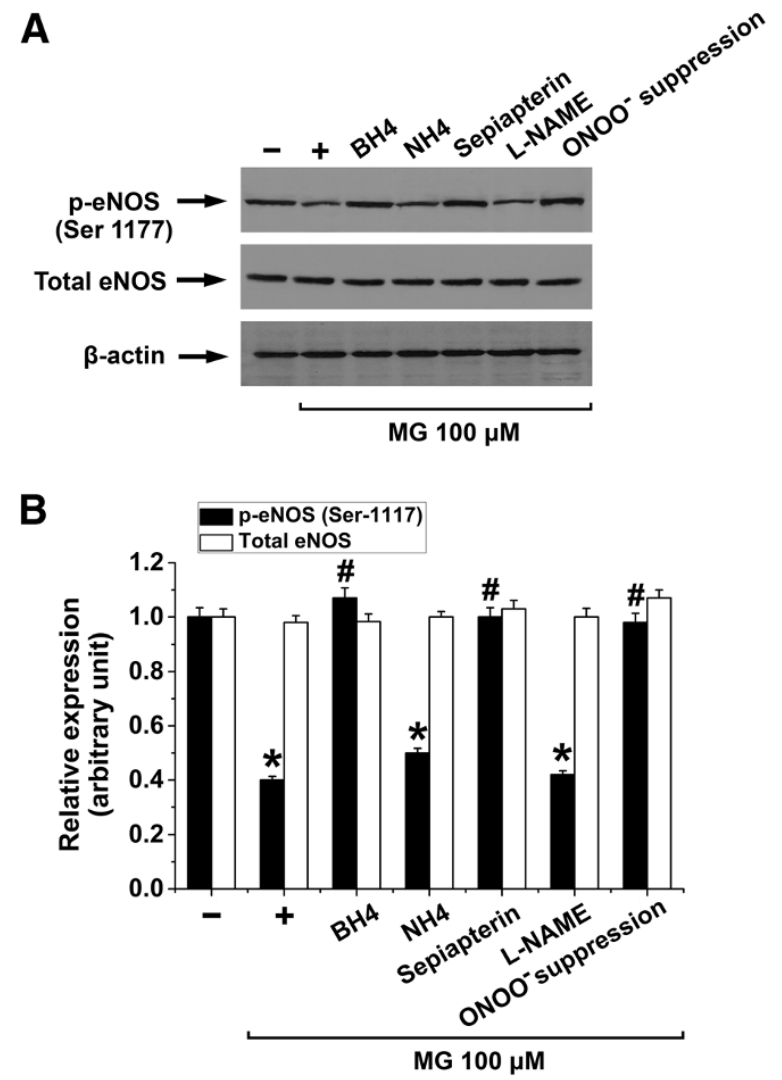

Figure 5 Effect of methylglyoxal on eNOS phosphorylation in EA.hy926 endothelial cells. A and B. Original Western blots (A) and the respective densitometric analysis (B) of the relative abundance of total eNOS protein (white bars; relative to $\beta$-actin) and Ser-1177 phospho-eNOS (black bars; relative to $\beta$-actin) in EA.hy296 endothelial cells incubated in the absence $(-)$ or in the presence of MG $(100 \mu \mathrm{M})$ for $8 \mathrm{~h}$ alone (+) or with $100 \mu \mathrm{M} \mathrm{BH} 4,100 \mu \mathrm{M} \mathrm{NH} 4,20$ $\mu \mathrm{M}$ sepiapterin or $50 \mu \mathrm{M}$ L-NAME in the last $4 \mathrm{~h}$ of MG treatment or with $24 \mathrm{~h}$ pre-treatment with $300 \mu \mathrm{M}$ Tempol and $50 \mu \mathrm{M}$ L-NAME (ONOO ${ }^{-}$suppression). Data are arithmetic means \pm SEM ( $\mathbf{A}$, representative of three experiments; $\mathbf{B}, n=3)$. * indicates significant difference $(p<0.05)$ from the absence of MG (ANOVA). \# indicates significant difference $(p<0.05)$ from MG treatment alone (ANOVA).

Oxidative stress is a salient feature of the pathophysiology of diabetes. The glycolysis metabolite MG was previously shown to affect redox balance by stimulating ROS production and modulating the expression and functions of cytoprotective molecules such as glutathione [40], superoxide dismutase [41], glyoxalase [42] and $\mathrm{H}_{2} \mathrm{~S}$ [43]. Increased NADPH oxidase-derived $\mathrm{O}_{2}^{--}$reacts with eNOS-derived $\mathrm{NO}$ to generate $\mathrm{ONOO}^{-}$which oxidizes $\mathrm{BH} 4$ to $\mathrm{BH} 2$. $\mathrm{BH} 4$ reduction has been implicated in the pathogenesis of a variety of conditions such as hyperphenylalaninemia [44], diabetes [45], ischemiareperfusion injury [46], hypertension [47], Alzheimer disease and Parkinson's disease [48], and many of these pathological conditions were shown to be ameliorated by exogenous BH4 [44-47] or sepiapterin [49-51] 
supplementation. BH4 is critical for the maintenance of eNOS dimers and is functionally related to $\mathrm{S}$-glutathionylation, a powerful regulator of eNOS uncoupling [52]. Our data that MG-triggered $\mathrm{O}_{2}^{--}$generation was inhibitable by L-NAME addition, $\mathrm{BH} 4$ or sepiapterin supplementation and $\mathrm{ONOO}^{-}$suppression clearly suggest the presence and contribution of uncoupled eNOS to $\mathrm{O}_{2}^{--}$generation in endothelial cell functions triggered by MG.

Mounting evidence suggests that phosphorylation of the residue Ser-1177 of eNOS via AKT stimulates NO production [53]. The effects of eNOS phosphorylation on eNOS uncoupling and $\mathrm{O}_{2}^{*-}$ production are not completely understood. Ser-1177 phosphorylation was shown to inhibit the $\mathrm{Ca}^{2+}$ sensitivity of eNOS and thus fosters $\mathrm{Ca}^{2+}$-independent $\mathrm{O}_{2}^{--}$generation [54]. In this study we tested the effect of $\mathrm{BH} 4$ supplementation on the hitherto known reduction of eNOS phosphorylation triggered by MG [30]. Our data show that supplementation of either $\mathrm{BH} 4$ or sepiapterin reversed MG-triggered reduction in Ser-1177 eNOS phosphorylation and enhanced eNOS uncoupling. Similar to BH4, other pharmacological agents such as nifedipine [55], nicorandil [56], and telmisartan [57] were shown to inhibit eNOS uncoupling and enhance eNOS phosphorylation and may, therefore, be beneficial in diabetic endothelial dysfunction. Furthermore, endogenous mediators such as C-reactive protein [58], IGF-1 [59], calcitriol [60], and 20-hydroxyeicosatetraenoic acid [61] were reported to modulate eNOS-associated functions. In this study we demonstrate for the first time the eNOS monomerization induced by the glycolysis metabolite MG and the effects of $\mathrm{BH} 4$ and sepiapterin supplementation on MG-modulated eNOS-associated functions in endothelial cells.

Uncoupling of eNOS is characterized by augmented tyrosine nitration which strongly indicates $\mathrm{ONOO}^{-}$-triggered cellular injury in diabetic hyperglycemia [62]. Increased placental protein tyrosine nitration was documented in diabetic patients [63] and, in animal models of diabetes, $3 \mathrm{NT}$ was shown to be enhanced in the kidney [64] and in the ventricle and lens [65]. Similarly, 3NT is upregulated in diabetic cardiomyopathy [66]. Our finding that $\mathrm{BH} 4$ but not NH4 supplementation abrogated enhanced 3NT expression in MG-treated endothelial cells supports the view that MG-induced depletion of eNOS factor $\mathrm{BH} 4$ is critical for MG-triggered eNOS uncoupling and endothelial dysfunction. Similar observations were also made in the diabetic heart subjected to ischemia-reperfusion injury [46], clearly indicating that exogenous BH4 supplementation may ameliorate diabetes-associated multi-organ pathologies.

Conflicting reports on eNOS expression in diabetic endothelial dysfunction suggest the complexity of the signalling mechanisms associated with eNOS during hyperglycemia. Treatment of endothelial cells with high concentrations of glucose was reported to have decreased eNOS protein expression in vitro [67]. It was also reported that the abundance of total and phosphorylated eNOS was reduced in internal mammary arteries of diabetic patients [68]. In old Zucker diabetic fatty rats, eNOS protein expression was demonstrated to be decreased [69]. On the contrary, in diabetic and apolipoprotein E-deficient mice, eNOS mRNA levels were augmented [70]. In a contrasting report, however, eNOS expression was shown to be unaltered in type 2 diabetic $\mathrm{db} / \mathrm{db}$ mice [71]. Along those lines, the discordant effects of MG treatment on eNOS functions reported previously may, thus, not be unexpected [27-30]. It is, however, intriguing to speculate that MG may be one of the essential metabolites that triggers eNOS hypophosphorylation and uncoupling encountered in diabetes.

\section{Conclusions}

We conclude that the intermediate glycolysis metabolite MG is a powerful modulator of eNOS functions in vascular endothelial cells in vitro. Administration of $\mathrm{BH} 4$ or its precursor sepiapterin or suppression of $\mathrm{ONOO}^{-}$ formation replenishes cellular $\mathrm{BH} 4$ levels, reverses hypophosphorylation of eNOS and ameliorates $\mathrm{O}_{2}^{*-}$ generation, 3NT upregulation and eNOS monomerization that are associated with MG-triggered eNOS uncoupling in endothelial cells. These pharmacological measures may indicate promising therapeutic benefits in MGsensitive endothelial dysfunction in diabetes.

\section{Abbreviations}

MG: Methylglyoxal; eNOS: Endothelial nitric oxide synthase; NO: Nitric oxide; $\mathrm{BH} 4$ : 5,6,7,8-tetrahydrobiopterin; $\mathrm{NH} 4$ : 5,6,7,8-tetrahydroneopterin; $\mathrm{BH}$ 2: 7, 8-dihydrobiopterin; L-NAME: N ${ }^{G}$-nitro-L-arginine methyl ester; Tempol: 1-oxyl-2, 2,6,6-tetramethyl-4-hydroxypiperidine; $\mathrm{O}_{2}^{--}$: Superoxide; $\mathrm{ONOO}^{-}$: Peroxynitrite; 3NT: 3-Nitrotyrosine; NADPH: Nicotinamide adenine dinucleotide phosphate; HSP90: Heat shock protein 90; LOX-1: Lectin-type oxidized LDL receptor 1; IGF-1: Insulin-like growth factor 1.

\section{Competing interests}

The authors declare that they have no conflict of interest.

\section{Authors' contributions}

Participated in research design: YS, SMQ, LW, and LL; conducted experiments: YS; performed data analysis and interpretation: YS, SMQ, and LL; contributed to the writing of the manuscript: YS, SMQ, and LL; critically revised the manuscript: LW and LL; all authors read and approved the final manuscript.

\section{Acknowledgments}

This work is supported in part by research grants to L. Liu from Canadian Institutes of Health Research (ClHR) and Natural Sciences and Engineering Research Council of Canada (NSERC). Y. Su is supported by a scholarship from China Scholarship Council. L. Liu is a recipient of CIHR New Investigator Award. S.M. Qadri is supported by a postdoctoral fellowship from the Saskatchewan Health Research Foundation (SHRF).

\section{Author details}

${ }^{1}$ Department of Pharmacology, College of Medicine, University of Saskatchewan, 107 Wiggins Road, Saskatoon, SK, Canada. ${ }^{2}$ Department of Health Sciences, Lakehead University and Thunder Bay Regional Research Institute, Thunder Bay, ON, Canada. 
Received: 25 July 2013 Accepted: 2 September 2013

Published: 19 September 2013

\section{References}

1. Hartge MM, Unger T, Kintscher U: The endothelium and vascular inflammation in diabetes. Diab Vasc Dis Res 2007, 4:84-88.

2. Kitasato L, Tojo T, Hatakeyama Y, Kameda R, Hashikata T, Yamaoka-Tojo M: Postprandial hyperglycemia and endothelial function in type 2 diabetes: focus on mitiglinide. Cardiovasc Diabetol 2012, 11:79.

3. Chen X, Mori T, Guo Q, Hu C, Ohsaki Y, Yoneki Y, et al: Carbonyl stress induces hypertension and cardio-renal vascular injury in Dahl salt-sensitive rats. Hypertens Res 2013, 36:361-367.

4. Nicolay JP, Schneider J, Niemoeller OM, Artunc F, Portero-Otin M, Haik G Jr, et al: Stimulation of suicidal erythrocyte death by methylglyoxal. Cell Physiol Biochem 2006, 18:223-232.

5. Gawlowski T, Stratmann B, Stirban AO, Negrean M, Tschoepe D: AGEs and methylglyoxal induce apoptosis and expression of Mac-1 on neutrophils resulting in platelet-neutrophil aggregation. Thromb Res 2007, 121:117-126.

6. Price $\mathrm{CL}$, Hassi $\mathrm{HO}$, English NR, Blakemore Al, Stagg AJ, Knight SC: Methylglyoxal modulates immune responses: relevance to diabetes. J Cell Mol Med 2010, 14:1806-1815.

7. Kuntz S, Kunz C, Rudloff S: Carbonyl compounds methylglyoxal and glyoxal affect interleukin- 8 secretion in intestinal cells by superoxide anion generation and activation of MAPK p38. Mol Nutr Food Res 2010, 54:1458-1467.

8. Jan $\mathrm{CR}$, Chen $\mathrm{CH}$, Wang SC, Kuo SY: Effect of methylglyoxal on intracellular calcium levels and viability in renal tubular cells. Cell Signal 2005, 17:847-855.

9. Wang H, Liu J, Wu L: Methylglyoxal-induced mitochondrial dysfunction in vascular smooth muscle cells. Biochem Pharmacol 2009, 77:1709-1716.

10. Su Y, Lei $X, W u L$, Liu L: The role of endothelial cell adhesion molecules $P$ selectin, E-selectin and intercellular adhesion molecule-1 in leucocyte recruitment induced by exogenous methylglyoxal. Immunology 2012, 137:65-79.

11. Chan WH, Wu HJ: Methylglyoxal and high glucose co-treatment induces apoptosis or necrosis in human umbilical vein endothelial cells. J Cell Biochem 2008, 103:1144-1157.

12. Tejero J, Stuehr D: Tetrahydrobiopterin in nitric oxide synthase. IUBMB Life 2013, 65:358-365

13. Buckley BJ, Mirza Z, Whorton AR: Regulation of $\mathrm{Ca}(2+)$-dependent nitric oxide synthase in bovine aortic endothelial cells. Am J Physiol 1995, 269:C757-C765.

14. Fleming I, Busse R: Molecular mechanisms involved in the regulation of the endothelial nitric oxide synthase. Am J Physiol Regul Integr Comp Physiol 2003, 284:R1-R12

15. Wheatcroft SB, Williams IL, Shah AM, Kearney MT: Pathophysiological implications of insulin resistance on vascular endothelial function. Diabet Med 2003, 20:255-268.

16. Montezano AC, Touyz RM: Reactive oxygen species and endothelial function-role of nitric oxide synthase uncoupling and Nox family nicotinamide adenine dinucleotide phosphate oxidases. Basic Clin Pharmacol Toxicol 2012, 110:87-94.

17. Ravi K, Brennan LA, Levic S, Ross PA, Black SM: S-nitrosylation of endothelial nitric oxide synthase is associated with monomerization and decreased enzyme activity. Proc Natl Acad Sci USA 2004, 101:2619-2624

18. Sawabe $K$, Yamamoto $K$, Harada Y, Ohashi A, Sugawara Y, Matsuoka H, et al: Cellular uptake of sepiapterin and push-pull accumulation of tetrahydrobiopterin. Mol Genet Metab 2008, 94:410-416.

19. Shimazu T, Otani H, Yoshioka K, Fujita M, Okazaki T, Iwasaka T: Sepiapterin enhances angiogenesis and functional recovery in mice after myocardial infarction. Am J Physiol Heart Circ Physiol 2011, 301:H2061-H2072.

20. Lorin J, Zeller M, Guilland JC, Cottin Y, Vergely C, Rochette L: Arginine and nitric oxide synthase: Regulatory mechanisms and cardiovascular aspects. Mol Nutr Food Res 2013. doi:10.1002/mnfr.201300033.

21. Kietadisorn R, Juni RP, Moens AL: Tackling endothelial dysfunction by modulating NOS uncoupling: new insights into its pathogenesis and therapeutic possibilities. Am J Physiol Endocrinol Metab 2012, 302:E481-E495.

22. Srivastava K, Bath PM, Bayraktutan U: Current therapeutic strategies to mitigate the eNOS dysfunction in ischaemic stroke. Cell Mol Neurobiol 2012, 32:319-336

23. Cai S, Khoo J, Mussa S, Alp NJ, Channon KM: Endothelial nitric oxide synthase dysfunction in diabetic mice: importance of tetrahydrobiopterin in eNOS dimerisation. Diabetologia 2005, 48:1933-1940.
24. Shevalye H, Watcho P, Stavniichuk R, Dyukova E, Lupachyk S, Obrosova IG: Metanx alleviates multiple manifestations of peripheral neuropathy and increases intraepidermal nerve fiber density in Zucker diabetic fatty rats. Diabetes 2012, 61:2126-2133.

25. Stalker TJ, Gong Y, Scalia R: The calcium-dependent protease calpain causes endothelial dysfunction in type 2 diabetes. Diabetes 2005, 54:1132-1140.

26. Desai KM, Chang T, Wang H, Banigesh A, Dhar A, Liu J, et al: Oxidative stress and aging: is methylglyoxal the hidden enemy? Can J Physiol Pharmacol 2010, 88:273-284.

27. Lin X, Amore A, Loiacono E, Balegno S, Manniello D, Peruzzi L, et al: Effect of glucose degradation products, glucose-containing dialysate and icodextrin on AQP1 and eNOS expression in cultured endothelial cells. J Nephrol 2009, 22:117-122.

28. Wang X, Jia X, Chang T, Desai K, Wu L: Attenuation of hypertension development by scavenging methylglyoxal in fructose-treated rats. J Hypertens 2008, 26:765-772

29. Mukohda M, Morita T, Okada M, Hara Y, Yamawaki H: Long-term methylglyoxal treatment causes endothelial dysfunction of rat isolated mesenteric artery. J Vet Med Sci 2013, 75:151-157.

30. Dhar A, Dhar I, Desai KM, Wu L: Methylglyoxal scavengers attenuate endothelial dysfunction induced by methylglyoxal and high concentrations of glucose. Br J Pharmacol 2010, 161:1843-1856.

31. Sankaralingam $S, X u H$, Jiang $Y$, Sawamura T, Davidge ST: Evidence for increased methylglyoxal in the vasculature of women with preeclampsia: role in upregulation of LOX-1 and arginase. Hypertension 2009, 54:897-904.

32. Targosz-Korecka M, Brzezinka GD, Malek KE, Stepien E, Szymonski M: Stiffness memory of EA.hy926 endothelial cells in response to chronic hyperglycemia. Cardiovasc Diabetol 2013, 12:96.

33. Heitzer T, Brockhoff C, Mayer B, Warnholtz A, Mollnau H, Henne S, et al: Tetrahydrobiopterin improves endothelium-dependent vasodilation in chronic smokers : evidence for a dysfunctional nitric oxide synthase. Circ Res 2000, 86:E36-E41.

34. Woo HJ, Kang JY, Choi YK, Park YS: Production of sepiapterin in Escherichia coli by coexpression of cyanobacterial GTP cyclohydrolase I and human 6-pyruvoyltetrahydropterin synthase. Appl Environ Microbiol 2002, 68:3138-3140.

35. Yang YM, Huang A, Kaley G, Sun D: eNOS uncoupling and endothelial dysfunction in aged vessels. Am J Physiol Heart Circ Physiol 2009, 297:H1829-H1836

36. Chang T, Wang R, Wu L: Methylglyoxal-induced nitric oxide and peroxynitrite production in vascular smooth muscle cells. Free Radic Biol Med 2005, 38:286-293.

37. Wang H, Meng $\mathrm{QH}$, Chang T, Wu L: Fructose-induced peroxynitrite production is mediated by methylglyoxal in vascular smooth muscle cells. Life Sci 2006, 79:2448-2454.

38. Batandier C, Fontaine E, Keriel C, Leverve XM: Determination of mitochondrial reactive oxygen species: methodological aspects. J Cell Mol Med 2002, 6:175-187.

39. Tarpey MM, Fridovich I: Methods of detection of vascular reactive species: nitric oxide, superoxide, hydrogen peroxide, and peroxynitrite. Circ Res 2001, 89:224-236.

40. Price $\mathrm{CL}$, Knight SC: Methylglyoxal: possible link between hyperglycaemia and immune suppression? Trends Endocrinol Metab 2009, 20:312-317.

41. Kang $\mathrm{JH}$ : Modification and inactivation of human $\mathrm{Cu}, \mathrm{Zn}$-superoxide dismutase by methylglyoxal. Mol Cells 2003, 15:194-199.

42. Di LS, Zimmitti V, Sebastiani P, Cervelli C, Falone S, Amicarelli F: Methylglyoxal causes strong weakening of detoxifying capacity and apoptotic cell death in rat hippocampal neurons. Int J Biochem Cell Biol 2008, 40:245-257.

43. Chang T, Untereiner A, Liu J, Wu L: Interaction of methylglyoxal and hydrogen sulfide in rat vascular smooth muscle cells. Antioxid Redox Signal 2010, 12:1093-1100.

44. Kim HK, Ha SH, Han J: Potential therapeutic applications of tetrahydrobiopterin: from inherited hyperphenylalaninemia to mitochondrial diseases. Ann N Y Acad Sci 2010, 1201:177-182.

45. Abudukadier A, Fujita Y, Obara A, Ohashi A, Fukushima T, Sato Y Tetrahydrobiopterin has a glucose-lowering effect by suppressing hepatic gluconeogenesis in an endothelial nitric oxide synthasedependent manner in diabetic mice. Diabetes 2013, 62:3033-3043.

46. Okazaki T, Otani H, Shimazu T, Yoshioka K, Fujita M, Katano T, et al: Reversal of inducible nitric oxide synthase uncoupling unmasks tolerance to 
ischemia/reperfusion injury in the diabetic rat heart. J Mol Cell Cardiol 2011, 50:534-544.

47. Khoo JP, Zhao L, Alp NJ, Bendall JK, Nicoli T, Rockett K, et al: Pivotal role for endothelial tetrahydrobiopterin in pulmonary hypertension. Circulation 2005, 111:2126-2133.

48. Foxton RH, Land JM, Heales SJ: Tetrahydrobiopterin availability in Parkinson's and Alzheimer's disease; potential pathogenic mechanisms. Neurochem Res 2007, 32:751-756.

49. Cheng H, Wang H, Fan X, Paueksakon P, Harris RC: Improvement of endothelial nitric oxide synthase activity retards the progression of diabetic nephropathy in db/db mice. Kidney Int 2012, 82:1176-1183.

50. Thida M, Earl J, Zhao Y, Wang H, Tse CS, Vickers JJ, et al: Effects of sepiapterin supplementation and NOS inhibition on glucocorticoidinduced hypertension. Am J Hypertens 2010, 23:569-574.

51. Tiefenbacher CP, Lee CH, Kapitza J, Dietz V, Niroomand F: Sepiapterin reduces postischemic injury in the rat heart. Pflugers Arch 2003, 447:1-7.

52. Crabtree MJ, Brixey R, Batchelor H, Hale AB, Channon KM: Integrated redox sensor and effector functions for tetrahydrobiopterin- and glutathionylation-dependent endothelial nitric-oxide synthase uncoupling. J Biol Chem 2013, 288:561-569.

53. McCabe TJ, Fulton D, Roman LJ, Sessa WC: Enhanced electron flux and reduced calmodulin dissociation may explain "calcium-independent" eNOS activation by phosphorylation. J Biol Chem 2000, 275:6123-6128.

54. Chen CA, Druhan $L$, Varadharaj S, Chen YR, Zweier JL: Phosphorylation of endothelial nitric-oxide synthase regulates superoxide generation from the enzyme. J Biol Chem 2008, 283:27038-27047.

55. Yamamoto E, Nakamura T, Kataoka K, Tokutomi Y, Dong YF, Fukuda M, et al: Nifedipine prevents vascular endothelial dysfunction in a mouse model of obesity and type 2 diabetes, by improving eNOS dysfunction and dephosphorylation. Biochem Biophys Res Commun 2010, 403:258-263.

56. Serizawa K, Yogo K, Aizawa K, Tashiro Y, Ishizuka N: Nicorandil prevents endothelial dysfunction due to antioxidative effects via normalisation of NADPH oxidase and nitric oxide synthase in streptozotocin diabetic rats. Cardiovasc Diabetol 2011, 10:105.

57. Wenzel P, Schulz E, Oelze M, Muller J, Schuhmacher S, Alhamdani MS, et al AT1-receptor blockade by telmisartan upregulates GTP-cyclohydrolase I and protects eNOS in diabetic rats. Free Radic Biol Med 2008, 45:619-626.

58. Singh U, Devaraj S, Vasquez-Vivar J, Jialal I: C-reactive protein decreases endothelial nitric oxide synthase activity via uncoupling. J Mol Cell Cardiol 2007, 43:780-791.

59. Ren J, Duan J, Thomas DP, Yang X, Sreejayan N, Sowers JR, et al: IGF-I alleviates diabetes-induced RhoA activation, eNOS uncoupling, and myocardial dysfunction. Am J Physiol Regul Integr Comp Physiol 2008, 294:R793-R802.

60. Hirata M, Serizawa K, Aizawa K, Yogo K, Tashiro Y, Takeda S, et al: 22-Oxacalcitriol prevents progression of endothelial dysfunction through antioxidative effects in rats with type 2 diabetes and early-stage nephropathy. Nephrol Dial Transplant 2013, 28:1166-1174.

61. Cheng J, Ou JS, Singh H, Falck JR, Narsimhaswamy D, Pritchard KA Jr, et al: 20-hydroxyeicosatetraenoic acid causes endothelial dysfunction via eNOS uncoupling. Am J Physiol Heart Circ Physiol 2008, 294:H1018-H1026.

62. Ceriello A, Novials A, Ortega E, Canivell S, Pujadas G, La SL, et al: Vitamin C further improves the protective effect of GLP-1 on the ischemiareperfusion-like effect induced by hyperglycemia post-hypoglycemia in type 1 diabetes. Cardiovasc Diabetol 2013, 12:97.

63. Johnston PC, Powell LA, McCance DR, Pogue K, McMaster C, Gilchrist S, et al: Placental protein tyrosine nitration and MAPK in type 1 diabetic preeclampsia: Impact of antioxidant vitamin supplementation. J Diabetes Complications 2013, 27:322-327.

64. Osorio H, Coronel I, Arellano A, Pacheco U, Bautista R, Franco M, et al: Sodium-glucose cotransporter inhibition prevents oxidative stress in the kidney of diabetic rats. Oxid Med Cell Longev 2012, 201 (2):542042.

65. Sakul A, Cumaoglu A, Aydin E, Ari N, Dilsiz N, Karasu C: Age- and diabetesinduced regulation of oxidative protein modification in rat brain and peripheral tissues: consequences of treatment with antioxidant pyridoindole. Exp Gerontol 2013, 48:476-484.

66. Huynh K, Kiriazis H, Du XJ, Love JE, Gray SP, Jandeleit-Dahm KA, et al: Targeting the upregulation of reactive oxygen species subsequent to hyperglycemia prevents type 1 diabetic cardiomyopathy in mice. Free Radic Biol Med 2013, 60:307-317.
67. Ding Y, Vaziri ND, Coulson R, Kamanna VS, Roh DD: Effects of simulated hyperglycemia, insulin, and glucagon on endothelial nitric oxide synthase expression. Am J Physiol Endocrinol Metab 2000, 279:E11-E17.

68. Okon EB, Chung AW, Rauniyar P, Padilla E, Tejerina T, McManus BM, et al: Compromised arterial function in human type 2 diabetic patients. Diabetes 2005, 54:2415-2423.

69. Lu X, Guo X, Karathanasis SK, Zimmerman KM, Onyia JE, Peterson RG, et al: Rosiglitazone reverses endothelial dysfunction but not remodeling of femoral artery in Zucker diabetic fatty rats. Cardiovasc Diabetol 2010, 9:19.

70. Ding H, Hashem M, Wiehler WB, Lau W, Martin J, Reid J, et al: Endothelial dysfunction in the streptozotocin-induced diabetic apoE-deficient mouse. Br J Pharmacol 2005, 146:1110-1118.

71. Pannirselvam M, Ding H, Anderson TJ, Triggle CR: Pharmacological characteristics of endothelium-derived hyperpolarizing factor-mediated relaxation of small mesenteric arteries from $\mathrm{db} / \mathrm{db}$ mice. Eur J Pharmacol 2006, 551:98-107.

\section{doi:10.1186/1475-2840-12-134}

Cite this article as: Su et al:: Methylglyoxal modulates endothelial nitric oxide synthase-associated functions in EA.hy926 endothelial cells.

Cardiovascular Diabetology 2013 12:134.

\section{Submit your next manuscript to BioMed Central and take full advantage of:}

- Convenient online submission

- Thorough peer review

- No space constraints or color figure charges

- Immediate publication on acceptance

- Inclusion in PubMed, CAS, Scopus and Google Scholar

- Research which is freely available for redistribution

Submit your manuscript at www.biomedcentral.com/submit
C Biomed Central 